\title{
PEMBERDAYAAN EKONOMI MASYARAKAT DALAM PENGEMBANGAN DESTINASI WISATA BARU BERBASIS ECOTOURISM DI KABUPATEN BANYUWANGI
}

\author{
Oleh: \\ Ahmad Izza Muttaqin \\ IAI Ibrahimy Genteng \\ izza@iaiibrahimy.ac.id
}

\begin{abstract}
:
The purpose of this study is to describe community economic empowerment in developing new tourist destinations based on ecotourism and describe the factors that influence the economic empowerment of the community in developing tourist destinations in Banyuwangi district. This research use desciptive qualitative approach. Locations of community economic empowerment research in the development of new ecotourism-based tourist destinations are in the Primitive Village of Purwodadi Village, Gambiran District, Tourism Objects of Pine Mangrove in Temborejo Village, Muncar District and Sumberum Village, Songgon District, Banyuwangi Regency. The research location is the object of research, the research activities carried out were randomly selected. In this study, the sources of research data are primary data and secondary data. The data analysis uses data reduction, data display and conclusion drawing / verification. Broadly speaking, community economic empowerment in the development of new ecotourism-based tourist destinations is carried out by means of; a) The involvement of the community around the new tourist destinations in various types of management and utilization of these destinations b) Strengthening the surrounding human resources as workers with certain criteria and needs c) Providing business space especially small and medium micro businesses in filling the tenants of new tourist destinations. D) Strengthening tourism management by providing sustainable tourism management counseling.
\end{abstract}

Keywords: policy implementation, community economic empowerment

\section{A. Pendahuluan}

Pengembangan industri pariwisata di Indonesia beberapa tahun terakhir memang tidak seperti Negara tetangga. Akan tetapi perlahan tapi pasti industri pariwisata di Indonesia kian tumbuh dan berkembang dan mungkin saja tidak lama lagi akan menyamai pencapaian industri pariwisata Negara tetangga. Hal tersebut dilatarbelakangi oleh jumlah

$$
\begin{array}{l|l}
\text { JURNAL LISAN AL-HAL } & 51
\end{array}
$$


kunjungan wisatawan mancanegara yang terus naik dan stabilitas keamanan di Indonesia. Walaupun disadari masih banyak yang perlu dibenahi, khususnya bidang infrastruktur penunjang pariwisata.

Banyak daerah di Indonesia yang mulai sadar akan potensi industri pariwisatanya. Salah satu daerah tersebut adalah Kabupaten Banyuwangi. Kabupaten Banyuwangi merupakan kabupaten dengan daratan paling luas di pulau Jawa yang mempunyai potensi luar biasa. Potensi tersebut berupa Pegunungan Ijen yang berbatasan dengan Kabupaten Jember, Bondowoso dan Situbondo. Potensi. Banyuwangi juga mempunyai dataran rendah yang luas dan subur yang ditumbuhi beraneka ragam tanaman, baik tanaman pangan maupun tanaman perkebunan. Banyuwangi juga beruntung karena terletak bersebelahan dengan Pulau Bali yang hanya dibatasi Selat Sunda. Pulau Bali sendiri bagian dari destinasi unggulan Indonesia yang menjadi tujuan wisata kelas dunia.

Potensi Banyuwangi yang begitu banyak itu sebenarnya sudah dikembangkan untuk industri pariwisata oleh Pemerintah Kabupaten BanyuwangiBanyuwangi, tetapi dampaknya dirasakan kurang maksimal. Salah satu indikatornya adalah angka kemiskinan di Kabupaten Banyuwangi pada tahun 2009 masih tinggi dan pendapatan domestic bruto yang juga masih rendah. Dari dua indikator tersebut diyakini bahwa pariwisata belum berdampak signifikan bagi perekonomian masyarakat di Kabupaten Banyuwangi.

Pada Tahun 2010, Pemerintah Kabupaten Banyuwangi di bawah komando Abdullah Azwar Anas, dan salah satu misinya adalah menjadikan pariwisata sebagai pengungkit perekonomian masyarakat Banyuwangi. Melalui tangan dingin Anas, sektor pariwisata mulai menunjukkan progress yang menggembirakan. Tentu saja bukan hal mudah memetakan dan menyelesaikan permasalah yang ada di sector pariwisata. Salah satu program yang diluncurkan oleh Anas adalah Banyuwangi Festival. Banyuwangi Festival adalah rangkaian kegiatan pariwisata yang berlangsung selama kurun waktu satu tahun dengan beberapa event ungggulan dank has yang menonjolkan kearifan lokal Kabupaten Banyuwangi.

Beberapa event unggulan Banyuwangi Festival mengangkat kahazanah kebudayaan Kabupaten Banyuwangi. Event-event tersebut dibagi menjadi kategori, diantaranya kebudayaan, kesenian, olah raga, keagamaan, dan social. Pembagian kategori dimaksudkan agar keberadaan Banyuwangi Festival dapat membawa dampak positif ke seluruh sektor kehidupan masyarakat Banyuwangi. Kategori kebudayaan misalnya ada even Gandrung Sewu, Banyuwangi Ethno Carnival (BEC), Festival Seblang,

$$
52 \text { JURNAL LISAN AL-HAL }
$$


Barong Ider Bumi dan sebagainya, yang mengangkat kekayaan budaya Suku Using. Kategori olah raga, International Banyuwangi Tour de Ijen menjadi event unggulan, disamping ada kejuaran surfing. Dalam Banyuwangi Festival sector social disentuh dengan Festival Anak Yatim, Sedekah Oksigen, dan Festival Bedah Rumah.

Pagelaran Banyuwangi Festival yang sudah dilangsungkan hampir tujuh tahun ini semakin berkembang. Beberapa raihan positif berhasil ditorehkan dan membawa nama Banyuwangi semakin dikenal di tingkat nasiona dan internasional. Salah satu pencapaian fenomenal adalah pada tahun 2016 Banyuwangi dinobatkan sebagai Pemerintah Daerah Terbaik Dunia dalam Pengembangan Pariwisata dari UNWTO yang diumumkan di Madrid Spanyol. Pencapaian lainnya adalah turunnya angka kemiskinan di Kabupaten Banyuwangi, yang pada awal kepemimpinan Pemkab Banyuwangi di angka dua digit, saat ini berhasil ditekan sampai kisaran 8 persen. Pendapatan domestik bruto juga mengalami peningkatan yang hampir 4 kali lipat. Dengan prestasi tersebut Banyuwangi dinilai sudah mampu mengandalkan industri pariwisata sebagai pendorong perekonomian masyarakat Kabupaten Banyuwangi sebagi penopang sector lainnya.

Upaya lainnya adalah dengan promosi yang massif di berbagai media massa dan media online. Upaya tersebut juga membuahkan hasil dengan semakin seringnya Banyuwangi masuk dalam pemberitaan nasional khususnya di bidang pariwisata. Upaya-upaya tersebut dilakukan dalam rangka mempertahankan raihan positif Kabupaten Banyuwangi di bawah kepemimpinan Bupati Abdullah Azwar Anas. Upaya tersebut juga menunjukkan bahwa pemerintah daerah sangat concern terhadap masalah pariwisata. Walaupun disadari industri pariwisata di Banyuwangi masih bertumpu pada destinasi mainstream spserti Kawah Ijen, Pulau Merah, Alas Purwo dan Sukamade. Akan tetapi destinasi-destinasi alternative juga mulai tumbuh dan berkembang.

Keberhasilan di bidang pariwisata menjadi semangat baru bagi desa-desa di Kabupaten Banyuwangi untuk semakin sadar potensinya. Terlebih desa yang mempunyai modal sumber daya alam yang memadai. Desa di Banyuwangi banyak potensi yang dapat dikembangkan menajdi destinasi wisata baru berbasis ecotourism. Akan tetapi pengembangan objek wisata baru berbasis ecotourism di Kabupaten Banyuwangi masih menemukan banyak hambatan.

Hambatan yang ditemui dalam pengembangan objek wisata baru berbasis ecotourism di Banyuwangi adalah masih banyaknya sumberdaya manusia yang belum siap menyambut dunia pariwisata. Di samping itu 
juga masih banyak desa yang belum sadar akaon potensi wisata yang ada di desanya. Masih minimnya keterlibatan stake holder dalam mengembangkan destinasi wisata baru juga perlu dicarikan solusinya.

Tingginya angka pengangguran di daerah objek wisata baru berbasis ecotorism di Kabupaten Banyuwangi menunjukkan belum adanya pelibatan masyarakat secara maksimal dalam memaksimalkan sumberdaya manusia yang ada. Dengan memberdayakan masyarakat sekitar khususnya yang berpenghasilan rendah maka secara tidak langsung akan mengangkat perekonomian masyarakat agar semakin sejahtera. Berdasarkan latar belakang tersebutk maka peneliti memiliki ketertarikan yang kuat untuk meneliti pemberdayaan ekonomi masyarakat dalam pengembangan destinasi wisata baru berbasis ecotourism di Kabupaten Banyuwangi.

\section{B. Metode Penelitian}

Penelitian ini menggunakan pendekatan deskriptif kualitatif. Hal ini bertujuan agar peneliti dapat menjelaskan secara jelas dan rinci informasi atau data yang diperoleh dalam penelitiannya secara mendalam. Alasan menggunakan metode ini, peneliti berusaha mencari fakta data kemudian mendeskripsikan mengenai pemberdayaan ekonomi masyarakat dalam pengembangan destinasi wisata berbasis ecotourism.

Lokasi penelitian di Objek Wisata Kampung Primitif Desa Purwodadi Kecamatan Gambiran, Objek Wisata Mangrove Cemara Desa Temborejo Kecamatan Muncar dan Desa Sumberum Kecamatan Songgon Kabupaten Banyuwangi. Lokasi penelitian adalah objek penelitian, kegiatan penelitian yang dilakukan yang dipilih secara acak.

Dalam penelitian ini yang menjadi sumber data penelitian ini adalah: Data primer, adalah data yang diperoleh secara langsung dari informan, yaitu informan utama masyarakat Desa Sumberarum Kecamatan Songgon Kabupaten Banyuwangi, dan informan pendukung yaitu Kepala Desa Sumberarum, Desa Purwodadi, Desa Temborejo, Manajer Perkebunanan Bayu Kidul, ADM KPH Perhutani Banyuwangi Barat dan tokoh masyarakat yang ada di Desa Sumberarum, Desa Purwodadi, Desa Temborejo, Sumber data primer diperoleh melalui pengamatan dan wawancara. Data skunder, adalah data yang diperoleh dengan mengambil bahan-bahan penelitian yang ada kaitannya dengan penelitian tentang pemberdayaan ekonomi masyarakat dalam pengembangan destinasi wisata berbasis ecotourism adalah di Desa Sumberarum, Desa Purwodadi, Desa Temborejo, Desa Sumberum Kabupaten Banyuwangi.

54 JURNAL LISAN AL-HAL 
Sugiyono menjelaskan bahwa dalam penelitian kualitatif, teknik pengumpulan data dilakukan dengan observasi, wawancara dan dokumentasi Penelitian tentang pemberdayaan ekonomi masyarakat dalam pengembangan destinasi wisata baru berbasis ecotourism adalah di Desa Sumberarum, Desa Purwodadi, Desa Temborejo Kabupaten Banyuwangi menggunakan beberapa metode, antara lain. Observasi, interview dan dokumentasi ${ }^{1}$.

Sugiyono menjelaskan bahwa dalam penelitian kualitatif yang menjadi instrumen adalah peneliti sendiri. Peneliti kualitatif sebagai human instrument, berfungsi menetapkan fokus penelitian, memilih informan sebagai sumber data, melakukan pengumpulan data, menilai kualitas data, analisis data, menafsirkan data dan membuat kesimpulan atas temuannya. Instrumen utama dalam penelitian ini adalah peneliti sendiri, namun peneliti juga menggunakan instrumen pendukung pendukung yaitu pedoman wawancara, pedoman observasi dan pedoman dokumentasi yang dibuat sendiri oleh peneliti2 .

Miles dan Huberman dalam Sugiyono mengemukakan bahwa aktifitas dalam analisis data kualitatif dilakukan secara interaktif dan berlangsung secara terus menerus sampai tuntas, sehingga datanya sudah jenuh. Aktifitas dalam analisis data yaitu, data reduction, data display dan conclusion drawing/ verification. Tahap-tahap analisis data dalam penelitian ini yaitu:

Pertama, Data Reduction. Mereduksi data berarti merangkum, memilih hal-hal yang pokok, memfokuskan pada hal-hal yang penting, dicari tema dan polanya dan membuang yang tidak perlu. Dengan demikian data yang telah direduksi akan memberikan gambaran yang lebih jelas dan mempermudah peneliti untuk melakukan pengumpulan data selanjutnya dan mencarinya bila diperlukan.

Kedua, Data Display. Dalam penelitian kualitatif, penyajian data bisa dilakukan dalam bentuk uraian singkat, bagan, hubungan antar kategori, flowchart dan sejenisnya. Dalam hal ini Miles dan Huberman dalam Sugiyono menyatakan bahwa yang paling sering digunakan untuk menyajikan data dalam penelitian kualitatif adalah dengan teks yang bersifat naratif. Dengan mendisplaykan data, maka akan memudahkan peneliti untuk memahami apa yang terjadi, merencanakan kerja yang

1 Sugiyono. Metode Penelitian: Pendekatan Kuantitatif, kualitatif, dan R\&D. (Bandung: Alfabeta. 2010), 309.

2 Sugiyono. Metode Penelitian: Pendekatan Kuantitatif, kualitatif, dan R\&D. (Bandung: Alfabeta. 2010), 305-306. 
selanjutnya berdasarkan apa yang telah difahami tersebut.

Ketiga, Conclusion Drawing/ Verification. Langkah ketiga dalam analisis data kualitatif menurut Miles dan Huberman dalam Sugiyono adalah penarikan kesimpulan dan verifikasi. Kesimpulan awal yang dikemukakan masih bersifat sementara dan akan berubah bila tidak ditemukan bukti-bukti yang kuat yang mendukung pada tahap pengumpulan data berikutnya. Tetapi apabila kesimpulan yang dikemukakan pada tahap awal didukung oleh bukti-bukti yang valid dan konsisten saat peneliti kembali ke lapangan mengumpulkam data, maka kesimpulan yang dikemukakan merupakan kesimpulan yang kredibel.

\section{Pembahasan}

\section{Pemberdayaan Ekonomi Masyarakat}

Pemberdayaan menurut bahasa berasal dari kata daya yang berarti tenaga/ kekuatan, proses, cara, perbuatan memberdayakan ${ }^{3}$. Pemberdayaan adalah upaya yang membangun daya masyarakat dengan mendorong, memotivasi dan membangkitkan kesadaran akan potensi yang dimiliki serta berupaya untuk mengembangkannya ${ }^{4}$.

Menurut Karl Marx dalam Mardi, pemberdayaan masyarakat adalah proses perjuangan kaum powerless untuk memperolah surplus value sebagai hak normatifnya. Perjuangan memperoleh surplus value dilakukan melalui distribusi penguasaan faktor-faktor produksi. Dan perjuangan untuk mendistribusikan penguasaan faktor-faktor produksi harus dilakukan melalui perjuangan politik ${ }^{5}$.

Contoh yang lebih umum dari problem spesifik yang dihadapi masyarakat tunadaya, diketahui bahwa salah satu dari tujuan akhir pemberdayaan masyarakat dalam bidang ekonomi adalah peningkatan kesejahteraan masyarakat miskin. Pendapatan masyarakat pada umumnya berasal dari dua anasir, yaitu dari upah/gaji dan dari surplus usaha. Dari anasir upah/gaji, pada umumnya masyakat yang tunadaya hanya menerima upah/gaji rendah. Rendahnya gaji/upah yang diterima masyarakat tunadaya ini disebabkan karena mereka pada umumnya memiliki ketrampilan yang terbatas dan sikap mental yang buruk (need

\footnotetext{
3 Pusat Bahasa Departemen Pendidikan Nasional, Kamus Besar Bahasa Indonesia, Jakarta: Balai Pustaka. 2002. 242.

4 Sukalele, Daniel, Pemberdayaan Masyarakat Miskin di Era Otonomi Daerah", (Bandung: Remaja Rosda Karya. 2014), 25.

5 Mardi, Yatmo Hutomo. Pemberdayaan Masyarkat dalam Bidang Ekonomi : Tinjauan Teoritik dan Implementasi, Naskah No.20 Juni-Juli. 2000, 23.

56 JURNAL LISAN AL-HAL
} 
achievment rendah, tidak disiplin). Rendahnya ketrampilan masyarakat tunadaya disebabkan karena akses atau kesempatan mereka untuk mendapatkan pelayanan pendidikannya pada umumnya buruk.

Demikian pula dari anasir surplus usaha. Sebagian besar masyarakat tunadaya tidak memiliki usaha, atau kalaupun memiliki, maka mereka menghadapi kendala dalam hal modal, dan atau tanah, dan atau kemampuan sumberdaya manusia, dan distribusi (baik pada pasar input maupun pada pasar output atau pasar barang). Keempat kendala ini saling berkaitan satu sama lain. Oleh sebab itu dalam rangka pemberdayaan ekonomi masyarakat dari sisi surplus usaha, maka perlu ditangani secara komprehensif.

Penanganan kendala modal, kendala distribusi, dan kendala tanah tidak seluruhnya dapat dilakukan melalui pendekatan ekonomi semata. Karena banyak dimensi-dimensi politik yang harus ditangani. Oleh sebab itu, pemberdayaan ekonomi masyarakat tidak dapat dilakukan tanpa pemberdayaan politik dan kebijakan politik. Tesis ini, kalau diterima, akan menuntut kepada kita semua, bahwa pemberdayaan ekonomi masyarakat harus menjadi komitmen dan kebijakan semua departemen. Sebab sekali lagi, dimensi yang harus ditangani dalam pemberdayaan masyarakat dalam bidang ekonomi, bersifat multi.

Konsep pemberdayaan yang dimaksud dalam penelitian ini adalah konsep pemberdayaan ekonomi yang diterapkan dalam pengembangan destinasi wisata baru berbasis ecotourism Kabupaten Banyuwangi. Ekonomi masyarakat adalah segala kegiatan ekonomi dan upaya masyarakat untuk memenuhi kebutuhan hidupnya (basic need) yaitu sandang, pangan, papan, kesehatan dan pendidikan. Dengan demikian dapat dipahami bahwa pemberdayaan ekonomi masyarakat merupakan satu upaya untuk meningkatkan kemampuan atau potensi masyarakat dalam kegiatan ekonomi guna memenuhi kebutuhan hidup serta meningkatkan kesejahteraan mereka dan dapat berpotensi dalam proses pembangunan nasional ${ }^{6}$.

Dengan demikian dapat disimpulkan bahwa pemberdayaan ekonomi masyarakat adalah satu upaya untuk meningkatkan kemampuan atau potensi masyarakat dalam kegiatan ekonomi guna memenuhi kebutuhan hidup serta meningkatkan kesejahteraan mereka dan dapat berpotensi dalam proses pembangunan nasional. Sedangkan yang dimaksud dengan pemberdayaan ekonomi masyarakat dalam penelitian

${ }^{6}$ Sukalele, Daniel, Pemberdayaan Masyarakat Miskin di Era Otonomi Daerah", (Bandung: Remaja Rosda Karya. 2014), 25. 
ini adalah satu upaya untuk meningkatkan kemampuan atau potensi masyarakat dalam kegiatan ekonomi guna memenuhi kebutuhan hidup serta meningkatkan kesejahteraan mereka dan dapat berpotensi dalam proses pembangunan nasional dalam pengembangan destinasi wisata baru berbasis ecotourism di Kabupaten Banyuwangi.

\section{Ekotourism}

Ekowisata lebih populer dan banyak dipergunakan dibanding dengan terjemahan yang seharusnya dari istilah ecotourism, yaitu ekoturisme. Terjemahan yang seharusnya dari ecotourism adalah wisata ekologis. Yayasan Alam Mitra Indonesia membuat terjemahan ecotourism dengan ekoturisme. Di dalam tulisan ini dipergunakan istilah ekowisata yang banyak digunakan oleh para rimbawan. Hal ini diambil misalnya dalam salah satu seminar dalam Reuni Fakultas Kehutanan Universitas Gadjah Mada. Kemudian Nasikun, mempergunakan istilah ekowisata untuk menggambarkan adanya bentuk wisata yang baru muncul pada dekade delapan puluhan ${ }^{7}$.

Pengertian tentang ekowisata mengalami perkembangan dari waktu ke waktu. Namun, pada hakekatnva, pengertian ekowisata adalah suatu bentuk wisata yang bertanggungjawab terhadap kelestarian area yang masih alami (natural aren), memberi manfaat secara ekonomi dan mempertahankan keutuhan budava bagi masyarakat setempat. Atas dasar pengertian ini, bentuk ekowisata pada dasarnya merupakan bentuk gerakan konservasi yang dilakukan oleh penduduk dunia. Eco-traveler ini pada hakekatnya konservasionis.

Definisi ekowisata yang pertama diperkenalkan oleh organisasi The Ecotourism Society (1990) sebagai berikut: Ekowisata adalah suatu bentuk perjalanan wisata ke area alami yang dilakukan dengan tujuan mengkonservasi lingkungan dan melestarikan kehidupan dan kesejahteraan penduduk setempat. Semula ekowisata dilakukan oleh wisatawan pecinta alam yang menginginkan di daerah tujuan wisata tetap utuh dan lestari, di samping budaya dan kesejahteraan masyarakatnya tetap terjaga.

Namun dalam perkembangannya ternyata bentuk ekowisata ini berkembang karena banyak digemari oleh wisatawan. Wisatawan ingin berkunjung ke area alami, yang dapat menciptakan kegiatan bisnis. Ekowisata kemudian didefinisikan sebagai berikut: Ekowisata adalah

7 Fandeli, Chafid, Mukhlison. Pengusahaan Ekowisata, Fakultas Kehutanan Univ. Gadjah Mada Yogyakarta. 2000.

58 JURNAL LISAN AL-HAL 
bentuk baru dari perjalanan bertanggungjawab ke area alami dan berpetualang yang dapat menciptakan industri pariwisata (Eplerwood, 1999). Dari kedua definisi ini dapat dimengerti bahwa ekowisata dunia telah berkembang sangat pesat. Ternyata beberapa destinasi dari taman nasional berhasil dalam mengembangkan ekowisata ini.

Bahkan di beberapa wilayah berkembang suatu pemikiran baru yang berkait dengan pengertian ekowisata. Fenomena pendidikan diperlukan dalam bentuk wisata ini. Hal ini seperti yang didefinisikan oleh Australian Department of Tourism (Black, 1999) yang mendefinisikan ekowisata adalah wisata berbasis pada alam dengan mengikutkan aspek pendidikan dan interpretasi terhadap lingkungan alami dan budaya masyarakat dengan pengelolaan kelestarian ekologis. Definisi ini memberi penegasan bahwa aspek yang terkait tidak hanya bisnis seperti halnya bentuk pariwisata lainnya, tetapi lebih dekat dengan pariwisata minat khusus, alternative tourism atau special interest tourism dengan obyek dan daya tarik wisata alam.

Ecotourism yang dimaksud dalam penelitian ini adalah konsep pengembangan destinasi wisata baru dalam pemberdayaan ekonomi yang diterapkan dalam pengembangan destinasi wisata baru berbasis ecotourism di Desa Sumberarum Kecamatan Songgon Kabupaten Banyuwangi.

Pertama, Konsep pengembangan ecotourism. Untuk mengembangkan ekowisata dilaksanakan dengan cara pengembangan pariwisata pada umumnya. Ada dua aspek yang perlu dipikirkan. Pertama, aspek destinasi, kemudian kedua adalah aspek market. Untuk pengembangan ekowisata dilaksanakan dengan konsep product driven. Meskipun aspek market perlu dipertimbangkan namun macam, sifat dan perilaku obyek dan daya tarik wisata alam dan budaya diusahakan untuk menjaga kelestarian dan keberadaannya.

Pada hakekatnya ekowisata yang melestarikan dan memanfaatkan alam dan budaya masyarakat, jauh lebih ketat dibanding dengan hanya keberlanjutan. Pembangunan ekowisata berwawasan lingkungan jauh lebih terjamin hasilnya dalam melestarikan alam dibanding dengan keberlanjutan pembangunan. Sebab ekowisata tidak melakukan eksploitasi alam, tetapi hanya menggunakan jasa alam dan masyarakat untuk memenuhi kebutuhan pengetahuan, fisik/ dan psikologis wisatawan. Bahkan dalam berbagai aspek ekowisata merupakan bentuk wisata yang mengarah ke metatourism. Ekowisata bukan menjual destinasi tetapi menjual filosofi. Dari aspek inilah ekowisata tidak akan mengenal kejenuhan pasar. 
Kedua, Prinsip ecotourism. Pengembangan ekowisata di dalam kawasan hutan dapat menjamin keutuhan dan kelestarian ekosistem hutan. Ecotraveler menghendaki persyaratan kualitas dan keutuhan ekosistem. Oleh karenanya terdapat beberapa butir prinsip pengembangan ekowisata yang harus dipenuhi. Apabila seluruh prinsip ini dilaksanakan maka ekowisata menjamin pembangunan yang ecological friendly dari pembangunan berbasis kerakyatan (commnnity based). The Ecotourism Society (Eplerwood/1999) menyebutkan ada delapan prinsip, yaitu: Mencegah dan menanggulangi dampak dari aktivitas wisatawan terhadap alam dan budaya, pencegahan dan penanggulangan disesuaikan dengan sifat dan karakter alam dan budaya setempat.

Pendidikan konservasi lingkungan. Mendidik wisatawan dan masyarakat setempat akan pentingnya arti konservasi. Proses pendidikan ini dapat dilakukan langsung di alam. Pendapatan langsung untuk kawasan. Mengatur agar kawasan yang digunakan untuk ekowisata dan manajemen pengelola kawasan pelestarian dapat menerima langsung penghasilan atau pendapatan. Retribusi dan conservation tax dapat dipergunakan secara langsung untuk membina, melestarikan dan meningkatkan kualitas kawasan pelestarian alam.

Partisipasi masyarakat dalam perencanaan. Masyarakat diajak dalam merencanakan pengembangan ekowisata. Demikian pula di dalam pengawasan, peran masyarakat diharapkan ikut secara aktif. Penghasilan masyarakat. Keuntungan secara nyata terhadap ekonomi masyarakat dari kegiatan ekowisata mendorong masyarakat menjaga kelestarian kawasan alam. Menjaga keharmonisan dengan alam. Semua upaya pengembangan termasuk pengembangan fasilitas dan utilitas harus tetap menjaga keharmonisan dengan alam. Apabila ada upaya disharmonize dengan alam akan merusak produk wisata ekologis ini. Hindarkan sejauh mungkin penggunaan minyak, mengkonservasi flora dan fauna serta menjaga keaslian budaya masyarakat.

Daya dukung lingkungan pada umumnya, lingkungan alam mempunyai daya dukung yang lebih rendah dengan daya dukung kawasan buatan. Meskipun mungkin permintaan sangat banyak, tetapi daya dukunglah yang membatasi. Peluang penghasilan pada porsi yang besar terhadap negara. Apabila suatu kawasan pelestarian dikembangkan untuk ekowisata, maka devisa dan belanja wisatawan didorong sebesarbesarnya dinikmati oleh negara atau negara bagian atau pemerintah daerah setempat.

$60 \mid$ JURNAL LISAN AL-HAL 


\section{Hasil penelitian}

\section{Desa Sumberarum}

\section{Pola Pengelolaan Destinasi Wisata di Desa Sumberarum}

Sistem pengelolaan objek pariwisata di Desa Sumberarum Kecamatan Songgon Kabupaten Banyuwangi dibagi menjadi dua. Kelompok pertama adalah objek wisata yang dikelola oleh Bumdes dan Pokdarwis. Kelompok kedua adalah objek wisata yang dikelola oleh PT Tirta Harapan Perkebunan Bayu Kidul.

Pembagian pengalolan ini didasarkan pada penguasaan lokasi. Lokasi yang berada di tanah kas desa (TKD) Desa Sumberarum maka akan dikelola oleh Bumdes dan Pokdarwis. Sedangkan objek wisata yang terletak di lokasi Perkebunan Bayu Kidul langsung dikelola oleh manajemen PT Tirta Harapan selaku pemegang Hak Guna Usaha (HGU) Bayu Kidul.

Berikut ini adalah pembagian pola pengelolaan objek wisata:

a. Badan Usaha Milik Desa (Bumdes)/Kelompok Sadar Wisata (Pokdarwis) meliputi: 1) Air Terjun Lider; 2) Air Terjun Timur Curah; dan 3) Pendakian Gunung Raung.

b. PT Tirta Harapan Perkebunan Bayu Kidul destinasi wisatanya meliputi 1) Air Terjun Selendang Arum; 20 Air Terjun Telunjuk Raung; 3) Villa Bejong; dan 4) Perkebunan Cengkeh Bayu Kidul.

\section{Bentuk Pemberdayaan Ekonomi Masyarakat di Destinasi Wisata di Desa Sumberarum}

Masyarakat Desa Sumberarum Kecamatan Songgon Kabupaten Banyuwangi dalam pengelolaan destinasi wisata terlibat secara aktif. Peran aktif masyarakat diwujudkan dalam perencanaan, pelaksaanaan dan pengawasan pengelolaan destinasi wisata. Baik destinasi wisata yang dikelola oleh Bumdes/Pokdarwis atau yang dikelola oleh PT. Tirta Harapan Perkebunan Bayu Kidul.

Adapun bentuk pemberdayaan ekonomi masyarakat dalam pengelolaan destinasi wisata di Desa Sumberarum antara lain: a. Pemandu Wisata; b. Penyedia Jasa Akomodasi; c. Pedagang Makanan dan Minuman; d. Jasa Tukang; e. Jasa Parkir; f. Kuli Panggul Pendakian; g. Keamanan; Dan h. pekerjaan pendukung lainnya. 


\section{Faktor yang Mempengaruhi Pemberdayaan Ekonomi Masyarakat di Destinasi Wisata Desa Sumberarum}

\section{a. Faktor Internal}

Faktor internal yang mempengaruhi pemberdayaan ekonomi masyarakat di destinasi wisata Desa Sumberarum adalah sebagai berikut:

1) Sumberdaya manusia masyarakat Desa Sumberarum dinilai belum siap menjadi pelaku sector pariwisata yang professional, hal tersebut karena kurangnya pelatihan dan jam terbang;

2) Kultur budaya sebagian masyarakat Desa Sumberarum yang masih memegang tradisi dinilai menghambat pengembangan destinasi wisata bari di Desa Sumberarum;

3) Sarana prasarana dan fasilitas di beberapa destinasi wisata di Desa Sumberarum masih belum layak, hal tersebut karena proses birokrasi yang harus sesuai dengan prosedur;

4) Lemahnya manajemen pengelolaan destinasi wisata di Desa Sumberarum, khususnya yang di bawah Bumdes dan Pokdarwis, hal ini disebabkan minimya pengurus yang mempunyai pengalaman dalam pengelolaan destinasi wisata.

\section{b. Faktor Eksternal}

Faktor eksternal yang mempengaruhi pemberdayaan ekonomi masyarakat di destinasi wisata Desa Sumberarum adalah sebagai berikut:

1) Perilaku pengunjung destinasi wisata yang masih belum bisa menjaga lingkungan dan membuang sampah sembarangan menjadi masalah tersendiri;

2) Perkembangan teknologi informasi yang cepat membuat pengelola destinasi wisata di Desa Sumberarum harus terus berinovasi agar tidak ditinggal;

3) Dukungan Pemerintah Kabupaten Banyuwangi, Khususnya melalui Dinas Kebudayaan dan Pariwisata dan Dinas-dinas terhadap pengembangan destinasi wisata di Desa Sumberarum, dukungan tersebut berupa pelatihan pegelolaan destinasi wisata dan promosi;

\section{Kampung Primitif}

\section{Pola Pengelolaan Destinasi Wisata Kampung Primitif}

Sistem pengelolaan objek pariwisata di destinasi wisata Kampung Primitif Desa Purwodadi Kecamatan Gambiran Kabupaten Banyuwangi ini dibawah Kelompok Sadar Wisata (Pokdarwis). Pada mulanya Pokdarwis Kampung Primitif berdiri secara swadaya, akan tetapi saat ini telah menjadi unit usaha dari Bumdesa Desa Purwodadi.

$62 \mid$ JURNAL LISAN AL-HAL 
Dengan menjadi unit usaha Bumdes Desa Purwodadi maka setiap tahun Pokdarwis Kampung Primitif telah mendapatkan penyertaan modal dari APBDES Desa Purwodadi. Penyertaan modal tersebut dikhususkan untuk meningkatkan sarana prasarana dan manajemen pengelolaan destinasi wsiata Kampung Primitif. Dengan demikian telah terjadi kolaborasi pengelolaan yang saling menguntungkan agar Kampung Primitif tetap menjadi alternatif pilihan wisata masyarakat.

\section{Bentuk Pemberdayaan Ekonomi Masyarakat di Destinasi Wisata Kampung Primitif}

Masyarakat sekitar destinasi wisata Kampung Primitif juga dilibatkan dalam pengelolaan, pengembangan, dan pengawasan. Pelibatan tersebut terbukti mampu menambah value masyarakat sekitar secara ekonomi. Adapun bentuk pemberdayaan ekonomi masyarakat dalam pengelolaan destinasi wisata Kampung Primitif antara lain:

a. Masyarakat menyediakan lahannya untuk parkir kendaraan;

b. Talent orang primitif hanya mengambil masyarakat sekitar dengan kriteria tertentu;

c. Masyarakat sekitar dipersilakan membuka warung makanan dan minuman;

d. Masyarakat sekitar diprioritaskan dalam pemenuhan jasa tukang dan kuli untuk pembangunan.

3. Faktor yang Mempengaruhi Pemberdayaan Ekonomi Masyarakat di Destinasi Wisata Kampung Primitif

a. Faktor Internal

Faktor internal yang mempengaruhi pemberdayaan ekonomi masyarakat di destinasi wisata Kampung Primitif adalah sebagai berikut:

1) Ide kreatif masyarakat untuk menciptakan hal yang baru khususnya figur primitiv yang kemudian dikembangkan menjadi destinasi wisata baru;

2) Lingkungan yang masih alami dan asli menjadi daya tarik sendiri bagi destinasi wisata Kampung Primitif;

3) Masyarakat yang mendukung dengan antusias menjadi energi positif bagi Pokdarwis Kampung Primitif dalam menjaga keberlangsungannya;

4) Sarana prasarana dan fasilitas di beberapa destinasi wisata di Kampung Primitif masih dinilai belum layak, sehingga ke depan perlu ditingkatkan dengan upaya berbagai pihak; 
5) Masih lemahnya manajemen pengelolaan destinasi wisata di Kampung Primitif, hal ini disebabkan minimya pengurus yang mempunyai pengalaman dalam pengelolaan destinasi wisata;

6) Tersedianya banyak talent yang bisa menambah daya tarik Kampung Primitif.

\section{b. Faktor Eksternal}

Faktor internal yang mempengaruhi pemberdayaan ekonomi masyarakat di destinasi wisata Kampung Primitif adalah sebagai berikut:

1) Perilaku pengunjung destinasi wisata hanya berorientasi pada pemenuhan gaya dengan berfoto selfie terkadang membuat abai terhadap kebersihan dan kenyamanan;

2) Perkembangan teknologi informasi yang cepat membuat pengelola destinasi wisata Kampung Primitif harus terus berinovasi agar tidak ditinggal dan tetap eksis di media sosial;

3) Dukungan Pemerintah Kabupaten Banyuwangi, Khususnya melalui Dinas Kebudayaan dan Pariwisata dan Dinas-dinas terhadap pengembangan destinasi wisata di Kampung Primitif, dukungan tersebut berupa pelatihan pegelolaan destinasi wisata dan promosi;

4) Permodalan dari Bumdes Desa Purwodadi dirasa cukup membantu pengembangan destinasi wisata Kampung Primitf, karena memang dibutuhkan biaya yang tidak sedikit dalam pengembangannya.

\section{Pantai Cemara}

\section{Pola Pengelolaan Destinasi Wisata Pantai Cemara Kawang}

Destinasi wisata Pantai Cemara Kawang Desa Wringinputih Kecamatan Muncar Kabupaten Banyuwangi dikelola oleh Kelompok Sadar Wisata (Pokdarwis) Mina Sero Laut yang sudah berbadan hukum. Pokdarwis ini bersifat swadaya yang beranggotakan masyarakat nelayan dan pembudidaya ikan di Desa Wringinputih. Termasuk dalam pembiayaan juga murni swadaya dari iuran anggota pada awalnya.

Seiring dengan semakin dikenalnya destinasi wisata Pantai Cemara Mangrove Kawang maka salah satu sumber income pokdarwis adalah dari tiket pengunjung yang dibanderol murah meriah. Dari salah satu income tersebut bisa digunakan untuk membayar karyawan dan investasi pengembangan destinasi wisata. Peningkatan kualitas layanan juga terus dikembangkan agar destinasi wisata Pantai Cemara Kawang semakin maju dan berkembang serta menjadi pilihan berwisata masyarakat.

$64 \mid$ JURNAL LISAN AL-HAL 


\section{Bentuk Pemberdayaan Ekonomi Masyarakat di Destinasi Wisata Pantai Cemara Kawang}

Masyarakat di sekitar destinasi wisata Pantai Cemara Kawang juga dilibatkan dalam pengelolaan, pengembangan, dan pengawasan. Pelibatan tersebut terbukti mampu menambah value masyarakat yang masyoritas nelayan sekitar secara ekonomi. Adapun bentuk pemberdayaan ekonomi masyarakat dalam pengelolaan destinasi wisata Pantai Cemara Kawang antara lain:

a) Masyarakat mendapat tambahan pengasilan dari tangkapan udang dan biota mangrove;

b) Masyarakat mendapat penghasilan dari jasa parkir, menjual makanan dan minuman;

c) Masyarakat menjual bibit mangrove untuk ditanam oleh pengunjung di lahan yang disediakan;

d) Masyarakat sekitar diprioritaskan dalam pemenuhan jasa tukang dan kuli untuk pembangunan.

\section{Faktor yang Mempengaruhi Pemberdayaan Ekonomi Masyarakat} di Destinasi Wisata Pantai Cemara Kawang

\section{a. Faktor Internal}

Faktor internal yang mempengaruhi pemberdayaan ekonomi masyarakat di destinasi wisata Pantai Cemara Kawang adalah sebagai berikut:

1) Hutan mangrove yang masih lebat dan luas menjadi modal utama dalam pengembangan destinasi wisata berbasis lingkungan;

2) Kesadaran masyarakat yang tinggi terhadap pentingnya menjaga mangrove sebagai penahan abrasi alami;

3) Sarana prasarana dan fasilitas di destinasi wisata Pantai Cemara Mangrove masih dinilai belum layak, sehingga ke depan perlu ditingkatkan dengan upaya berbagai pihak;

4) Pengelolaan Pantai Cemara Mangrove Kawang dinilai masih butuh banyak penyempurnaan, karena memang masih tahun 2016 mulai dikembangkan;

\section{b. Faktor Eksternal}

Faktor internal yang mempengaruhi pemberdayaan ekonomi masyarakat di destinasi wisata Kampung Primitif adalah sebagai berikut:

1) Perilaku pengunjung destinasi wisata hanya berorientasi pada pemenuhan gaya dengan berfoto selfie terkadang membuat abai terhadap kebersihan dan kenyamanan; 
2) Eksistensi pengelola dalam "mengiklankan" Pantai Cemara Mangrove dalam media sosial perlu ditingkatkan untuk lebih semarak dalam promosi;

3) Dukungan Pemerintah Kabupaten Banyuwangi, Khususnya melalui Dinas Kebudayaan dan Pariwisata dan Dinas-dinas terhadap pengembangan destinasi wisata di Pantai Cemara Mangrove, dukungan tersebut berupa pelatihan pegelolaan destinasi wisata, promosi, dan pembangunan jalan akses;

\section{E. Simpulan}

Dalam penelitian ini dapat disimpulkan bahwa pemberdayaan ekonomi masyarakat dalam pengembangan destinasi wisata baru berbasis ecotourism di Kabupaten Banyuwangi Secara garis besar dilakukan dengan cara; Pertama, pelibatan masyarakat sekitar destinasi wisata baru dalam berbagai jenis pengelolaan dan pemanfaatan destinasi tersebut. Kedua, Menguatamakan SDM sekitar sebagai tenaga kerja dengan kriteria dan kebutuhan tertentu. Ketiga, Memberikan ruang usaha khusunya usaka mikro kecil dan menengah dalam pengisian tenant-tenant destinasi wisata baru dan Keempat, Penguatan pengelolaan pariwisata dengan memberikan penyuluhan manajemen pariwisata secara berkelanjutan.

Untuk faktor-faktor yang Mempengaruhi Pemberdayaan ekonomi masyarakat dalam pengembangan destinasi wisata baru berbasis ecotourism terbagi ke dalam faktor internal dan eksternal. Faktor internal adalah faktor yang timbul dari pihak-pihak yang terlibat secara langsung dalam pemberdayaan ekonomi masyarakat dalam pengembangan destinasi wisata baru berbasis ecotourism. Beberapa faktornya antara lain: a) Kreativitas dari masyarakat untuk memunculkan destinasi wisata baru yang asyik, rekreatif dan berbasis lingkungan; 2) Tersedianya banyak lokasi yang bisa dikembangkan menjadi destinasi wisata baru berbasis lingkungan, 3) Keterbatasan sumber daya manusia (SDM) di bidang pariwisata, baik secara kualitas dan kuantitas; 4) Keterbatasan anggaran dalam pengembangan destinasi wisata baru karena berbagai alasan; dan 5) Partisipasi masyarakat yang kuat.

Faktor eksternal adalah faktor yang timbul dari pihak-pihak yang terlibat secara tidak langsung dalam pemberdayaan ekonomi masyarakat. Beberapa faktornya antara lain: 1) Kurangnya promosi yang digaungkan oleh Pemerintah Daerah Kabupaten Banyuwangi; 2) Perilaku wisatawan yang masih tidak taat aturan dan terkesan abai terhadap kebersihan lingkungan; dan 3) Masih ada destinasi wisata baru yang terkendala oleh sarana dan prasarana.

$66 \mid$ JURNAL LISAN AL-HAL 


\section{DAFTAR PUSTAKA}

Bungin. Burhan. Penelitian Kualitatif Komunikasi, Ekonomi, KebijakaN Publik dan Ilmu Sosial Lainnya. Jakarta: Kencana Prenada Media Group. 2011.

Fandeli, Chafid, Mukhlison. Pengusahaan Ekowisata, Fakultas Kehutanan Univ. Gadjah Mada Yogyakarta. 2000.

Friedmann. Empowement: the Politics of Alternative Development. Cambridge Mass: Blackwell Publisher. 2000.

Hutomo, Mardi Yatmo, Pemberdayaan Ekonomi Masyarakat. Jakarta; Unmuh Press. 2000.

Mardi, Yatmo Hutomo. 2000, Pemberdayaan Masyarkat dalam Bidang Ekonomi : Tinjauan Teoritik dan Implementasi, Naskah No.20 JuniJuli

Moleong, Lexy J. 2005. Metode Penelitian Kualitatif. Bandung: PT. Remaja Rosdakarya Offset.

Projono, O.S dan Pranarka, A.M.W.Pemberdayan: Konsep, Kebijakan dan implementasi. CSIS; Jakarta. 1996.

Pusat Bahasa Departemen Pendidikan Nasional, Kamus Besar Bahasa Indonesia, Jakarta: Balai Pustaka. 2002.

Sugiyono. Metode Penelitian: Pendekatan Kuantitatif, kualitatif, dan $\quad R \& D$. Bandung: Alfabeta. 2010.

Sumidiningrat, Gunawan. Pemberdayaan Masyarakat dan Jaring Pengaman Sosial. Gramedia; Jakarta. 1999.

Sukalele, Daniel, Pemberdayaan Masyarakat Miskin di Era Otonomi Daerah", Bandung: Remaja Rosda Karya. 2014.

Suwantoro, Gamal. Dasar-dasar Pariwisata. Yogyakarta: ANDI. 2004.

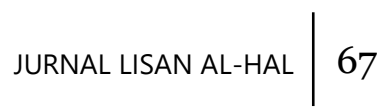


"Pengembangan Destinasi Wisata Berbasis Ecotourism"

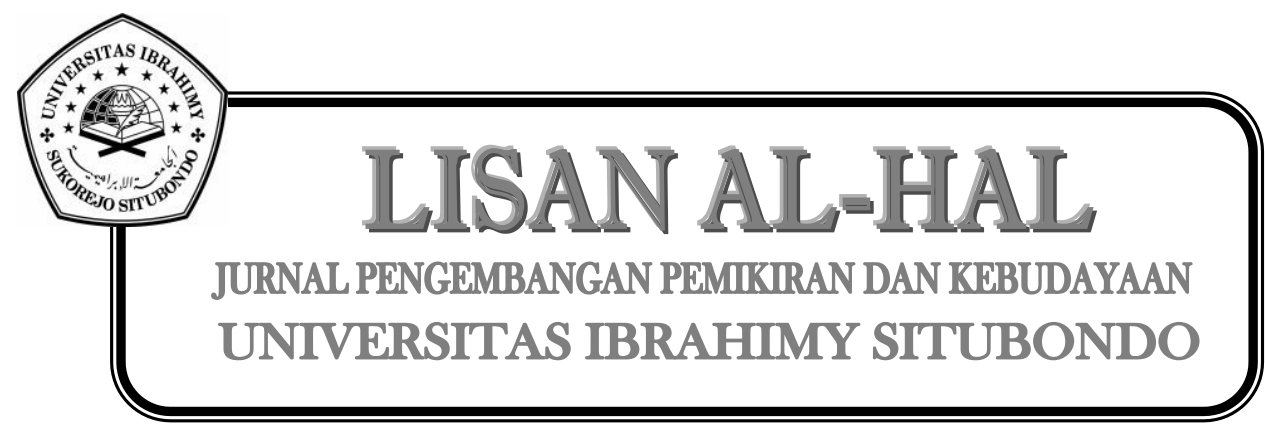

68 JURNAL LISAN AL-HAL 